\title{
Emission Assessment of Agro-Waste Combustion
}

\author{
Zuhal Akyürek $^{1^{*}}$, Afşin Güngör ${ }^{2}$

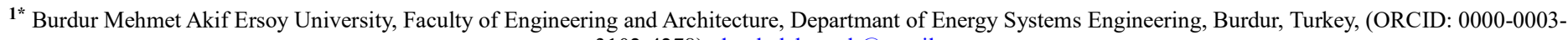 \\ 3102-4278), drzuhalakyurek@gmail.com \\ 2 Akdeniz University, Faculty of Engineering, Departmant of Mechanical Engineering, Antalya, Turkey, (ORCID: 0000-0002-4245-7741), afsingungor@hotmail.com
}

(First received 22 April 2021 and in final form 24 July 2021)

(DOI: 10.31590/ejosat.926468)

ATIF/REFERENCE: Akyürek, Z., Güngör, A. (2021). Emission Assessment of Agro-Waste Combustion. European Journal of Science and Technology, (27), 1-5.

\begin{abstract}
Biomass can be used to meet energy needs for electricity generation, residential and commercial buildings' heating, industrial process heating, transportation, etc. Future of bioenergy sector depends on the availability of biomass resources and development in conversion technologies. Fluidized bed combustion is a favorable technology for biomass combustion due its fuel flexible feature and enhanced combustion efficiency. In this study, the atmospheric emissions from fluidized bed combustion of agricultural residues such as wheat straw, corn stalk, rice husk, almond shell, walnut shell and sugarcane bagasse were estimated for 1 MW thermal energy production by using a mathematical combustion model. $\mathrm{CO}_{2}$ emissions from biomass can be regarded as zero due to the carbon neutral nature of biomass. Almond shell and sugarcane bagasse has shown the lowest $\mathrm{SO}_{2}$ and $\mathrm{NO}_{\mathrm{x}}$ emissions. Sugarcane bagasse has shown lower corrosion risk compared to the biomass types examined in this study. Performance and operation of biomass combustion can be enhanced by addition of limestone and additives for sulfur capturing and reducing the risk for ash related problems, respectively.
\end{abstract}

Keywords: Agricultural residues, fluidized bed, combustion, emission, environment.

\section{Tarımsal Atıkların Yanmasının Emisyon Değerlendirmesi}

\section{$\ddot{O} z$}

Biyokütle, elektrik üretimi, konut ve ticari binaların 1sıtılması, endüstriyel proses 1sıtması, ulaşım vb. gibi enerji ihtiyaçlarını karşılamak için kullanılabilir. Biyoenerji sektörünün geleceği, biyokütle kaynaklarının mevcudiyetine ve dönüştürme teknolojilerindeki gelişmeye bağlıdır. Akışkan yatakta yanma, yakıt esnek özelliği ve artırılmış yanma verimliliği nedeniyle biyokütle yanması için uygun bir teknolojidir. Bu çalışmada, buğday samanı, mısır sapı, pirinç kabuğu, badem kabuğu, ceviz kabuğu ve şeker kamışı küspesi gibi tarımsal artıkların akışkan yatakta yakılmasından kaynaklanan atmosferik emisyonlar, matematiksel bir yanma modeli kullanılarak $1 \mathrm{MW}$ termal enerji üretimi için değerlendirilmiştir. Biyokütlenin karbon nötr doğası nedeniyle biyokütleden $\mathrm{CO}_{2}$ emisyonları sıfır olarak kabul edilebilir. Badem kabuğu ve şeker kamışı küspesi en düşük $\mathrm{SO}_{2}$ ve $\mathrm{NO}_{\mathrm{x}}$ emisyonlarını göstermiştir. Şeker kamışı küspesi, bu çalışmada incelenen biyokütle türlerine kıyasla daha düşük korozyon riski göstermiştir. Biyokütle yanmasının performansı ve işleyişi, sırasıyla kireçtaşı eklenerek kükürtün tutulması ve katkı maddeleri eklenerek külle ilgili sorunların riskinin azaltılması ile artırılabilir.

Anahtar Kelimeler: Tarımsal Atık, akışkan yatak, yanma, emisyon, çevre.

\footnotetext{
*Corresponding Author: drzuhalakyurek@gmail.com
} 


\section{Introduction}

Increasing environmental concerns related with the utilization of fossil fuels for energy generation and continuous increase in global energy demand led to utilization of renewable sources. Biomass is the only carbon based renewable energy source to cope with climate change. Biomass usage in large-scale operations could help sustainable energy generation and energy security of nations. Biomass fuels have several advantages over fossil fuels as a renewable source of energy production with net zero greenhouse gas (GHG) emissions (Hoogwijk et al., 2003; Faaij, 2004; Nukman and Spahutar, 2015).

The residues and wastes from agricultural and forestry activities and industrial sectors, energy crops, livestock wastes, domestic wastes can be used as biomass feedstock (McKendry, 2002a). Biomass can be converted into energy and other forms of fuel through thermo-chemical (combustion, gasification, pyrolysis, liquefaction), biochemical (anaerobic digestion, fermentation) and physico-chemical (esterification) conversion technologies (Mesa et al., 2010).

Biomass could play significant role in renewable energy production with its high potential in the production of biofuels for electricity, heat and transportation. Selecting the most suitable technology for bio-waste processing can be carried out considering the efficiency and economy of technology. Among the alternatives, combustion is generally the most preferred technology for biomass processing for energy that $90 \%$ of the total renewable energy is obtained from biomass through combustion (Tursi, 2019). During combustion, biomass reacts with oxygen to produce carbon dioxide, water vapor and heat. The amount of the heat produced depends on the characteristics of biomass (moisture content, volatile matter content, ash composition, particle size, particle density, etc.), treatment technology and process parameters (Gogebakan, 2007). Biomass differs from conventional fossil fuels. Moisture content is one of the main parameters for choosing the combustion technology for biomass utilization. Combustion of biomass is regarded as feasible with a moisture content less than $50 \%$. High moisture content biomass is more applicable to biological conversion processes (McKendry, 2002b).

Biomass combustion is carried out in high temperature combustion chambers operating at around $800-1000{ }^{\circ} \mathrm{C}$ (Figure 1). Biomass combustion plants, which burn woody residues generally are able to generate $20-50 \mathrm{MW}$ to $50-80 \mathrm{MW}$ or much more electrical energy depending on the choice of technology (Tursi, 2019; McKendry, 2002b). Table 1 shows samples of the largest biomass energy plants in the World (Power Technology, 2014). In comparison with conventional combustion technologies, fluidized-bed combustion (FBC) is one of the most suitable and advanced technologies for energy recovery from biomass due to its fuel flexible feature which provides handling various types of fuels, low operating temperatures, low $\mathrm{SO}_{2}$ and $\mathrm{NO}_{\mathrm{x}}$ emissions (Arvelakis et al., 2001).

The objective of this study is to develop a combustion model capable of predicting the steady-state performance of a $1 \mathrm{MWth}$ atmospheric fluidized bed burning biomass. The model is used to determine the stack gas compositions of selected agricultural residues; wheat straw, corn stalk, rice husk, almond shell, walnut shell and sugarcane bagasse.

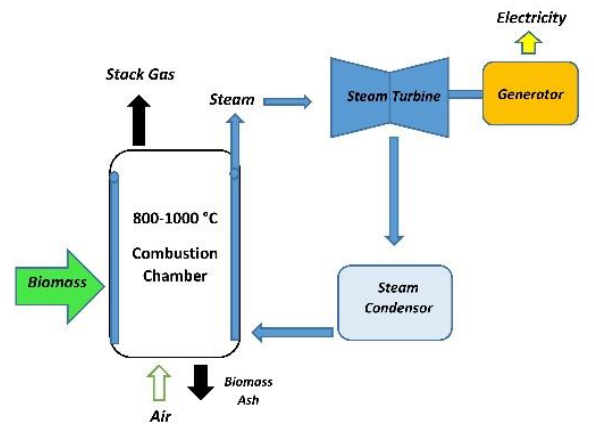

Figure 1 Biomass utilization in combustion chambers.

\section{Material and Method}

Mathematical modeling of biomass combustion could improve both the design and operation, reduce associated problems and facilitate the implementation of fluidized bed technology. The current model assumes isothermal operation and occurrence of chemical equilibrium. Five chemical species, $\mathrm{O}_{2}$, $\mathrm{CO}_{2}, \mathrm{H}_{2} \mathrm{O}, \mathrm{SO}_{2}, \mathrm{NO}_{2}$ are considered in the model. Uniform release of volatiles in the combustor are assumed. MATLAB program is used to elucidate the combustion mechanisms and calculate the stack gas emission.

The combustion reactions used in the program are given as follows:

$$
\begin{aligned}
& \mathrm{C}+\mathrm{O}_{2} \rightarrow \mathrm{CO}_{2} \\
& \mathrm{~S}+\mathrm{O}_{2} \rightarrow \mathrm{SO}_{2} \\
& \mathrm{~N}+\mathrm{O}_{2} \rightarrow \mathrm{NO}_{2} \\
& \mathrm{H}+0.5 \mathrm{O}_{2} \rightarrow \mathrm{H}_{2} \mathrm{O}
\end{aligned}
$$

Feeding rate of biomass $(\mathrm{kg} / \mathrm{h})$, biomass characteristic properties (proximate analysis, elemental analysis), excess air coefficient (1.2), Fuel nitrogen to NO conversion (5\%), ash split to fly ash $(70 \%)$ are taken as the input parameters for the model. $100 \%$ carbon conversion efficiency is assumed in the model. The stack gas compositions are calculated under certain operating conditions. The characterization of biomass used in this study is presented in Table 2.

\section{Results and Discussion}

Fluidized bed combustion is a proven technology for the conversion of agricultural residues to energy offering several economic and environmental benefits. This study aims to predict the stack gas emissions from 1 MWth bubbling fluidized bed combustor burning different types of biomass without limestone addition via a mathematical model. Gaseous emissions predicted by the model at the exit of the combustor for biomass under consideration are presented in Figure 2 and Figure 3. As can be seen from the figures, similar oxygen and water vapor concentrations were obtained for all biomass fuels and $70 \%$ of the stack gas concentration is composed of $\mathrm{N}_{2}$.

$\mathrm{CO}_{2}$ emission assessment has carried out in order to evaluate the impact of biomass in terms of global warming. As can be seen from the figure, similar $\mathrm{CO}_{2}$ emission values were obtained for all biomass. Due to the $\mathrm{CO}_{2}$ neutral feature of biomass fuels, their 
impact on global warming can be considered as negligible (Akyürek, 2019, 2021).

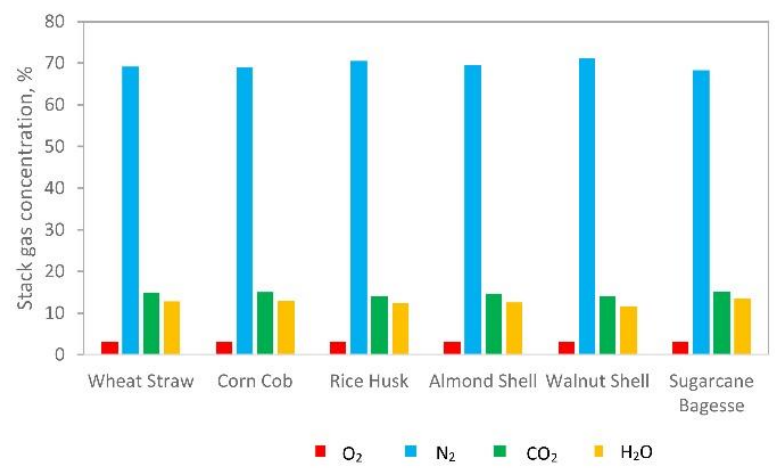

Figure 2 Model results for $\mathrm{O}_{2}, \mathrm{~N}_{2}, \mathrm{CO}_{2}, \mathrm{H}_{2} \mathrm{O}$ concentrations in stack gas, $\mathrm{mol} \%$.

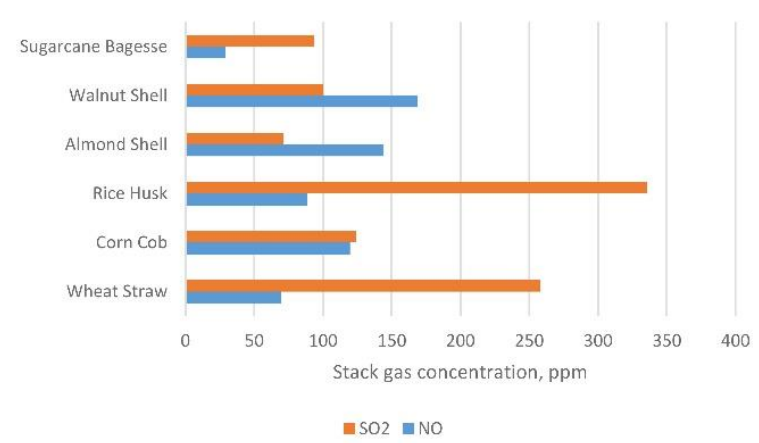

Figure 3 Model results for $\mathrm{NO}$ and $\mathrm{SO}_{2}$ concentrations in stack gas, ppm

Walnut shell has shown the highest NO concentration, 169 ppm, followed by almond shell, corn cob, rice husk, wheat straw and sugarcane bagasse in correspondence with the nitrogen contents of the feedstock. Highest sulfur dioxide concentration was determined for rice husk due to higher sulfur content of the feedstock, as 334 ppm followed by wheat straw, walnut shell, sugarcane bagasse and almond shell.
Emission limitations of air pollutants from the combustion of fuels in plants with a rated thermal input equal to or greater than 1 Megawatt thermal (MWth) and less than $50 \mathrm{MW}$ th are regulated by Directive (EU) 2015/2193 "the Medium Combustion Plant Directive (MCPD)".

Table 3 presents the simulation results of $\mathrm{NO}, \mathrm{SO}_{2}$ and dust emissions in comparison with the EU directive. The model results revealed that all the biomass focused in this study have lower $\mathrm{NO}_{\mathrm{x}}$ and dust emission potential than the limited values. In the case of $\mathrm{SO}_{2}$ emission, all the biomass has shown to exceed the limit. These results revealed the need for limestone addition to reduce the $\mathrm{SO}_{2}$ emission in order to fulfill the emission requirements.

Biomass ash, which is transformed into inorganic matter can stay in the boiler or can release to the environment in fly ash through the stack. Ash split to the bottom ash and fly ash generally depends on biomass characteristics and operating conditions. In the current model, $70 \%$ ash split to fly ash is assumed for biomass under consideration, respectively. During biomass combustion, ash split to fly ash can be much greater (80-90\%) in relation with the low bulk density of biomass tends to elutriate from fluidized bed boiler system (Gogebakan, 2007). Fly ash in the flue gas is generally collected through filters in order to reduce particulate emissions to the atmosphere from the stack. In this study, $99 \%$ of the fly ash is assumed to be captured. The fly ash flow rates of biomass are given in Table 4. Storage and recovery of the biomass ash is also significant due to their potential use in cement sector as additives (James et al., 2012).

Chlorine content in the feed biomass may result in problems in operation, which may lead to corrosion in the heat exchange surfaces in the boilers. Corrosion index, sulfur to chlorine ratio, can be used as an indicator of corrosiveness of the biofuels. Figure 4 shows the corrosion tendency of the biomass. Chlorine content of the fuel greater than $0.1 \%$ is indicative of corrosion risk on heat transfer surfaces (Niu et al, 2016). When $\mathrm{S} / \mathrm{Cl}$ ratio lower than 2 , there occurs corrosion risk. If the $\mathrm{S} / \mathrm{Cl}$ ratio is greater than 4 , then the biomass can be regarded as non-corrosive for fluidized bed combustion applications (Dayton et al., 1999; Vamvuka et al. 2008), All the bio-fuels under consideration has shown to have corrosion risk during their combustion.

Table 1 Largest biomass energy power plants in the world.

\begin{tabular}{|c|c|c|c|}
\hline Power Plant & Fuel & $\begin{array}{c}\text { Energy Generation } \\
\text { capacity }\end{array}$ & Country \\
\hline Ironbridge & Wood pellets & $740 \mathrm{MW}$ & United Kingdom \\
\hline Alholmens Kraft & Pulp, paper, timber & $265 \mathrm{MW}$ & Finland \\
\hline Kymijärvi II & $\begin{array}{c}\text { Plastic, paper, } \\
\text { cardboard and wood }\end{array}$ & $160 \mathrm{MW}$ & Finland \\
\hline $\begin{array}{c}\text { Vaasa Bio-gasification } \\
\text { plant }\end{array}$ & Forest residue & $140 \mathrm{MW}$ & Finland \\
\hline Wisapower & Black liquor & $140 \mathrm{MW}$ & Finland \\
\hline $\begin{array}{l}\text { New Hope Power } \\
\text { Partnership, }\end{array}$ & $\begin{array}{l}\text { Sugar cane bagasse, } \\
\text { recycled wood }\end{array}$ & $140 \mathrm{MW}$ & US \\
\hline Kaukaan Voima, & Wood, peat & $125 \mathrm{MW}$ & Finland \\
\hline Seinäjoki & Woodchips, peat & $125 \mathrm{MW}$ & Finland \\
\hline
\end{tabular}


Table 2 Analysis of biomass

\begin{tabular}{|c|c|c|c|c|c|c|}
\hline Biomass & $\begin{array}{l}\text { Wheat straw } \\
\text { (Arvelakis, } \\
\text { et al., 2001) }\end{array}$ & $\begin{array}{l}\text { Corn cob } \\
\text { (Rozainee, } \\
\text { 2010; Ibeto } \\
\text { et al., 2016) }\end{array}$ & $\begin{array}{c}\text { Rice husk } \\
\text { (Tsai, et al., } \\
\text { 2007) }\end{array}$ & $\begin{array}{c}\text { Almond } \\
\text { shell (Safari } \\
\text { et al., 2018) }\end{array}$ & $\begin{array}{l}\text { Walnut shell } \\
\text { (Saidur et al., } \\
\text { 2011) }\end{array}$ & $\begin{array}{c}\text { Sugarcane } \\
\text { bagasse } \\
\text { (Levendis et } \\
\text { al., 2011) }\end{array}$ \\
\hline \multicolumn{7}{|c|}{ Proximate Analysis (as received basis, wt. \%) } \\
\hline Moisture & 7.75 & 5.27 & 6.37 & 3.29 & 2.32 & 4.40 \\
\hline Ash & 5.74 & 0.21 & 11.70 & 3.16 & 2.56 & 4.00 \\
\hline Volatile Matter & 72.05 & 78.87 & 69.84 & 73.00 & 60.71 & 83.90 \\
\hline Fixed Carbon & 14.46 & 15.65 & 12.09 & 19.86 & 39.82 & 7.70 \\
\hline \multicolumn{7}{|c|}{ Ultimate Analysis (dry basis, wt. \%) } \\
\hline $\mathrm{C}$ & 46.95 & 48.00 & 48.36 & 47.88 & 53.60 & 44.30 \\
\hline $\mathrm{H}$ & 5.36 & 5.79 & 5.88 & 6.00 & 6.60 & 5.70 \\
\hline $\mathrm{N}$ & 0.51 & 0.89 & 0.72 & 1.10 & 1.50 & 0.20 \\
\hline $\mathrm{O}$ & 36.69 & 44.80 & 32.03 & 41.70 & 35.50 & 45.49 \\
\hline $\mathrm{S}$ & 0.22 & 0.11 & 0.31 & 0.06 & 0.10 & 0.07 \\
\hline $\mathrm{Cl}$ & 1.05 & 0.20 & 0.20 & 0.10 & 0.20 & 0.04 \\
\hline LHV, MJ/kg & 17.23 & 15.40 & 11.97 & 16.90 & 16.80 & 15.40 \\
\hline
\end{tabular}

Table 3 Emission limits set by EU Directive for Medium Combustion Plant and the calculated emission values for biomass

\begin{tabular}{lccc}
\hline Emission & $\mathbf{S O}_{2}, \mathbf{~ m g} / \mathbf{N m}^{\mathbf{3}}$ & $\mathbf{N O}_{\mathbf{x}}, \mathbf{~ m g} / \mathbf{N m}^{\mathbf{3}}$ & $\mathbf{D u s t}_{\mathbf{~}} \mathbf{~} \mathbf{/ N \mathbf { N m } ^ { \mathbf { 3 } }}$ \\
\hline EU Directive Limit & $200,300^{*}$ & 650 & 50 \\
\hline Biomass & & & 8.72 \\
Wheat straw & 737 & 93 & 0.33 \\
Corn cob & 365 & 160 & 15.86 \\
Rice husk & 959 & 119 & 4.41 \\
Almond shell & 204 & 193 & 2.99 \\
Walnut shell & 287 & 226 & 6.36 \\
Sugarcane bagasse & 267 & 39 & \\
\hline
\end{tabular}

$* 300 \mathrm{mg} / \mathrm{Nm}^{3}$ in the case of plants firing straw.

Table 4 Simulation results for bottom ash and fly ash flow rates

\begin{tabular}{lcc}
\hline Biomass & Bottom Ash, kg/h & Fly ash, $\mathrm{kg} / \mathrm{h}$ \\
\hline Wheat straw & 2.88 & 6.72 \\
Corn cob & 0.16 & 0.38 \\
Rice husk & 10.84 & 25.30 \\
Almond shell & 2.07 & 4.84 \\
Walnut shell & 1.69 & 3.94 \\
Sugarcane bagasse & 2.88 & 6.72 \\
\hline
\end{tabular}

Wheat straw has the highest chlorine content and its combustion in fluidized bed has generally carried out with additives during large-scale operations in order to reduce the corrosion of boilers heat exchange surfaces. Sugarcane bagasse has shown the lowest corrosion risk among the biomass under consideration.

\section{Conclusions and Recommendations}

Fossil fuel combustion is the most conventional route of energy production all around the world. In the last decades, population growth and technological improvements have exploited the fossil fuel consumption and hence anthropogenic emissions, which provoke the need for alternative clean energy sources.

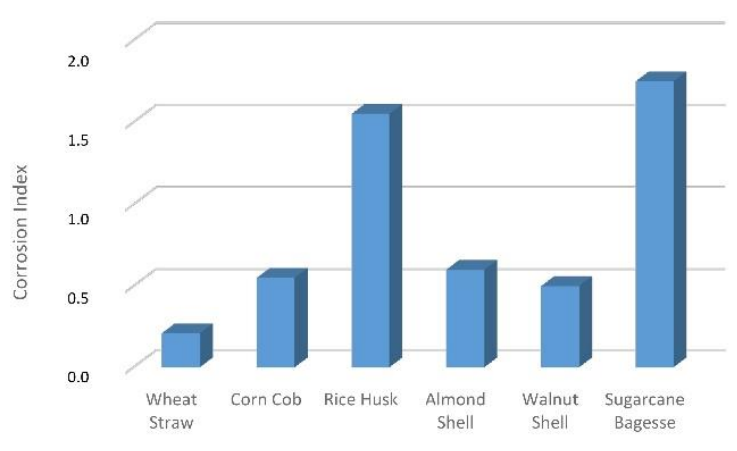

Figure 4 Corrosion risk in biofuels 
Biomass is the most promising energy source due to its carbon dioxide neutral nature. However, due to its structure, its thermal degradation is complicated. Fluidized bed combustion is the most suitable conversion technology for complex structured fuels such as biomass. Estimation of emissions from biomass combustion is challenging because the emission factors are highly depend on the biomass characteristics and operating conditions. This work has analyzed the biomass combustion and emission performance in a $1 \mathrm{MW}$ th fluidized bed combustor through a developed combustion model. The simulation results revealed that emission from biomass combustion is dependent on biomass characteristics and operational conditions. In order to be in the emission limits set by the European Union, biomass combustion should be carried out with limestone addition for sulfur retention. Using additives for mitigating the possible ash related operational problems could also ease the process of energy production from biomass.

\section{Acknowledge}

This research did not receive any specific grant from funding agencies in the public, commercial, or not-for-profit sectors.

\section{References}

Akyürek Z (2021) Synergetic Effects during Co-Pyrolysis of Sheep Manure and Recycled Polyethylene Terephthalate. Polymers 13(14): 2363. https://doi.org/10.3390/polym13142363

Akyürek Z (2019) Sustainable Valorization of Animal Manure and Recycled Polyester: Co-pyrolysis Synergy. Sustainability 11(8): 2280. https://doi.org/10.3390/su11082280

Arvelakis S, Vourliotis P, Kakaras E, Koukiosa EG (2001) Effect of leaching on the ash behavior of wheat straw and olive residue during fluidized bed combustion. Biomass and Bioenergy 20(6): 459-470. https://doi.org/10.1016/S09619534(01)00003-4

Dayton DC, Jenkins BM, Turn SQ, Bakker RR, Williams RB, Belle-Oudry D, Hill LM (1999) Release of inorganic constituents from leached biomass during thermal conversion. Energy and Fuels 13: 860. https://doi.org/10.1021/ef980256e

EU- The Medium Combustion Plant Directive Directive (EU) 2015/2193 of The European Parliament and of The Council, 25 November 2015. https://eur-lex.europa.eu/legalcontent/EN/TXT/PDF/?uri=CELEX:32015L2193\&from $=\mathrm{E}$

Faaij APC (2004) Biomass combustion. Encyclopedia of Energy 1: $175-191$.

Gogebakan Z (2007) Co-firing Biomass with Coal in Bubbling Fluidized Bed Combustors, $\mathrm{PhD}$ Thesis, Middle East Technical University.

Hoogwijk MM, Faaij APC, van den Broek R, Berndes G, Gielen D, Turkenburg DC (2003) Exploration of the ranges of the global potential of biomass for energy. Biomass and Bioenergy 25(2): 119-133. https://doi.org/10.1016/S09619534(02)00191-5

Ibeto CN, Ayodele JA, Anyanwu CN (2016) Evaluation of Pollution Potentials and Fuel Properties of Nigerian SubBituminous Coal and its blends with Biomass. J. Mater. Environ. Sci. 7 (8): 2929-2937.
James AK, Thring RW, Helle H, Ghuman HS (2012) Ash Management Review-Applications of Biomass Bottom Ash. Energies 5: 3856-3873; https://doi.org/10.3390/en510385

Levendis YA, Joshi K, Khatami R, Sarofim AF (2011) Combustion behavior in air of single particles from three different coal ranks and from sugarcane bagasse. Combustion and Flame 158: 452-465. https://doi.org/10.1016/j.combustflame.2010.09.007

McKendry P (2002a) Energy production from biomass (part 1): overview of biomass. Bioresource Technology 83: 37-46. https://doi.org/10.1016/S0960-8524(01)00118-3

McKendry P (2002b) Energy production from biomass (part 2): conversion technologies. Bioresource Technology 83: 47-54. https://doi.org/10.1016/S0960-8524(01)00119-5

Mesa L, González E, Ruiz E, Romero I, Cara C, Felissia F, Castro E (2010) Preliminary evaluation of organosolv pre-treatment of sugar cane bagasse for glucose production: Application of 23 experimental design. Applied Energy 87: 109-114. https://doi.org/10.1016/j.apenergy.2009.07.016

Niu Y, Tan H, Hui S (2016) Ash-related issues during biomass combustion: Alkali-induced slagging, silicate melt-induced slagging (ash fusion), agglomeration, corrosion, ash utilization, and related countermeasures. Progress in Energy and Combustion Science 52: 1-61. https://doi.org/10.1016/j.pecs.2015.09.003

Nukman, Spahutar R (2015) The Potential of Biomass from Wood, Leaves, and Grass as Renewable Energy Sources in South Sumatera, Indonesia. Energy Sources, Part A: Recovery, Utilization, and Environmental Effects 37: 27102715. https://doi.org/10.1080/15567036.2012.738286

Rozainee M, Ngo SP, Salema AA, Tan, KG (2010) Computational fluid dynamics modeling of rice husk combustion in a fluidized bed combustor. Powder Technology 203: 331-347. https://doi.org/10.1016/j.powtec.2010.05.026

Safari F, Javani N, Yumurtaci Z (2018) Hydrogen production via supercritical water gasification of almond shell over algal and agricultural hydrochars as catalysts. International Journal of Hydrogen Energy 43: 1071-1080. https://doi.org/10.1016/j.ijhydene.2017.05.102

Saidur R, Abdelaziz EA, Demirbas A, Hossaina MS, Mekhilef S (2011) A review on biomass as a fuel for boilers, Renewable and Sustainable Energy Reviews 15: 2262-2289. https://doi.org/10.1016/j.rser.2011.02.015.

The World Biggest Biomass Power Plants; https://www.powertechnology.com/features/featurepower-from-waste-theworlds-biggest-biomass-power-plants-4205990/

Tsai WT, Lee MK, Chang YM (2007) Fast pyrolysis of rice husk: Product yields and compositions. Bioresource Technology 98: 22-28. https://doi.org/10.1016/j.biortech.2005.12.005

Tursi A (2019) A review on biomass: importance, chemistry, classification, and conversion. Biofuel Research Journal 22: 962-979. https://doi.org/10.18331/BRJ2019.6.2.3

Vamvuka D, Zografos D, Alevizos G (2008) Control methods for mitigating biomass ash-related problems in fluidized beds. Bioresource Technology 99: 3334-3344. https://doi.org/10.1016/j.biortech.2007.07.049 